\title{
Comparison of three larval bioassays to evaluate susceptibility of Rhipicephalus (Boophilus) microplus to amitraz
}

\author{
Comparação de três bioensaios larvais para avaliar a suscetibilidade \\ de Rhipicephalus (Boophilus) microplus ao amitraz
}

Tânia Regina Bettin Santos ${ }^{*}$; Guilherme Marcondes Klafke²; Felipe Geraldo Pappen³;

Leandro Quintana Nizoli'; Patrícia Biegelmeyer ${ }^{4}$; Nara Amélia Rosa Farias ${ }^{5}$

\begin{abstract}
${ }^{1}$ Laboratório do Doenças Parasitárias, Departamento de Veterinária Preventiva, Faculdade de Veterinária, Universidade Federal de Pelotas - UFPel, Capão do Leão, RS, Brasil

${ }^{2}$ Laboratório de Parasitologia, Instituto de Pesquisas Veterinárias Desidério Finamor, Fundação Estadual de Pesquisa Agropecuária, Eldorado do Sul, RS, Brasil

${ }^{3}$ Laboratório de Parasitologia, Instituto Federal Catarinense - IFC, Campus Concórdia, Concórdia, SC, Brasil

${ }^{4}$ Programa de Pós-graduação em Zootecnia, Departamento de Zootecnia, Faculdade de Agronomia Eliseu Maciel, Universidade Federal de Pelotas - UFPel, Capão do Leão, RS, Brasil

${ }^{5}$ Laboratório de Parasitologia, Departamento de Microbiologia e Parasitologia, Instituto de Biologia, Universidade Federal de Pelotas - UFPel, Campus Capão do Leão, Capão do Leão, RS, Brasil
\end{abstract}

Received April 24, 2013

Accepted October 1, 2013

\begin{abstract}
Field samples of Rhipicephalus (Boophilus) microplus from the state of Rio Grande do Sul, Brazil, were assessed using the following methods: larval packet test (LPT), larval immersion test (LIT) and syringe immersion test (SIT). The following parameters were determined for each population and for the Mozo susceptible reference strain: lethal concentration for $50 \%\left(\mathrm{LC}_{50}\right)$ with its $95 \%$ confidence interval $(95 \% \mathrm{CI})$, regression line slope and resistance ratio (RR). Using the LPT, only one population was susceptible to amitraz, presenting a RR of 1.9. Using the same technique, the other populations presented RRs of between 92.9 and 3445.8 and were considered resistant. The $\mathrm{LC}_{50}$ of the Mozo strain calculated using the LPT, LIT and SIT was $2.9,27.3$, and $52.7 \mu \mathrm{g} / \mathrm{mL}$, respectively. In general, a good fit to the probit statistical model was only achieved using the LPT. The results obtained in this study impair recommendations for using the LIT and SIT to diagnose amitraz resistance in $R$. (B.) microplus populations. Additional studies are required to improve the sensitivity of these tests in relation to the LPT.
\end{abstract}

Keywords: Rhipicephalus (Boophilus) microplus, amitraz, bioassays, resistance diagnosis.

\section{Resumo}

Amostras de Rhipicephalus (Boophilus) microplus coletadas à campo no Rio Grande do Sul, Brasil, foram analisadas pelos seguintes métodos: teste do pacote de larvas (TPL), teste de imersão de larvas (TIL) e teste de imersão em seringas (TIS). Os seguintes parâmetros foram determinados para cada população e para a amostra referência suscetível Mozo: concentração letal para 50\% $\left(\mathrm{CL}_{50}\right)$ e seu intervalo de confiança de 95\% (IC95\%), inclinação da reta de regressão e os fatores de resistência (FR). Pelo TPL, apenas uma populaçâo foi sensível ao amitraz, com FR de 1,9. Utilizando a mesma técnica, as outras amostras apresentaram FR entre 92,9 e 3445,8 sendo consideradas resistentes. As $\mathrm{CL}_{50}$ da cepa Mozo calculadas por meio do TPL, TIL e TIS foram 2,9, 27,3 e 52,7 $\mu \mathrm{g} / \mathrm{mL}$, respectivamente. De forma geral, a adequação ao modelo estatístico de probitos só foi alcançada com o uso do TPL. Os resultados obtidos no presente estudo limitam a recomendação de uso do TIL e TIS para diagnóstico de resistência ao amitraz em populaçóes de $R$. (B.) microplus. Estudos adicionais são necessários para aprimorar a sensibilidade destes testes em relação ao LPT.

Palavras-chave: Rhipicephalus (Boophilus) microplus, amitraz, bioensaio, diagnóstico de resistência.

\footnotetext{
*Corresponding author: Tânia Regina Bettin Santos

Laboratório do Doenças Parasitárias, Departamento de Veterinária Preventiva,

Faculdade de Veterinária, Universidade Federal de Pelotas - UFPel, Campus

Capão do Leão, s/n, CP 354, CEP 96010-900, RS, Capão do Leão, Brasil

e-mail: trb.santos@hotmail.com
} 


\section{Introduction}

Parasitism by Rhipicephalus (Boophilus) microplus has a high impact on cattle production in tropical and subtropical areas around the world. This is aggravated by the increasing numbers of acaricide-resistant tick populations. Resistance is a hereditary characteristic, defined as a change in the genetic composition of a defined population in response to selection (CROW, 1957). The determinant process associated with development of resistance is continuous selection pressure, such as frequent use of a certain chemical product (KUNZ; KEMP, 1994).

Amitraz is the acaricide most used in the southern region of the state of Rio Grande do Sul, Brazil (VARGAS et al., 2003; FARIAS et al., 2008; SANTOS et al., 2009). It has some advantages over other acaricides, such as low toxicity to cattle and short withdrawal periods for milk (one day) and meat (14 days). The first amitraz-resistant cattle-tick population in Brazil was detected in 1994, subsequently, cases of resistance have been reported in other parts of this country (CAMPOS JÚNIOR.; OLIVEIRA, 2005; ANDREOTTI et al., 2011; VEIGA et al., 2012). In the state of Rio Grande do Sul, several cases of resistance have been reported (VARGAS et al., 2003; CAMILLO et al., 2009; SANTOS et al., 2009). Reduced in vitro efficacy of amitraz against $R$. (B.) microplus field populations has been noticed since 2000 (FARIAS et al., 2008).

Early detection of resistance is an important preventive tool for moderating the selection pressure exerted by acaricide treatments on the genes present in field populations (LI et al., 2005). Resistance in $R$. (B.) microplus can be diagnosed using the larval stage in in vitro bioassays: a) larval packet test (LPT), originally described by Stone and Haydock (1962), standardized by FAO (1971) and then modified by Miller et al. (2002), with the aim of specifically diagnosing amitraz resistance; b) larval immersion test (LIT), originally described by Shaw (1966), then adapted for microcentrifuge tubes by Sabatini et al. (2001) and used successfully for diagnosing resistance to ivermectin (KLAFKE et al. 2006, 2012) and fipronil (CASTRO-JANER et al., 2010); and c) syringe immersion test (SIT), described by Souza et al. (2008) although not yet standardized for routine use as an acaricide resistance diagnostic tool. Recently, Mendes et al. (2013) described the use of LIT for diagnosing amitraz resistance in $R$. (B.) microplus field populations, which presented satisfactory results. However, direct comparison of the performance of these three techniques for detecting resistance to amitraz has never been reported. Therefore, the purpose of this study was to evaluate the LIT and the SIT techniques as alternative assays to the LPT for discriminating amitraz-susceptible and resistant populations.

\section{Materials and Methods}

\section{Ticks}

Engorged female $R$. (B.) microplus specimens were collected from 20 ranches in the southern region of Rio Grande do Sul, Brazil, between March 2010 and March 2012. All the municipalities included in this study were located between the coordinates $31^{\circ} 45^{\prime} \mathrm{S} 52^{\circ} 30^{\prime} \mathrm{W}$ and $32^{\circ} 02^{\prime} \mathrm{S} 52^{\circ} 06^{\prime} \mathrm{W}$. Each population had a different history of exposure to amitraz. To obtain the larvae, a minimum of 30 engorged female ticks were collected from at least 10 different animals on each farm.

The Mozo strain was used as a susceptible reference strain. The engorged females from the field populations were taken to the parasitology laboratory of the Veterinary School of the Federal University of Pelotas (Laboratório de Doenças Parasitárias da Faculdade de Veterinária da Universidade Federal de Pelotas, $L A D O P A R)$. On arrival, the specimens were washed with running water, selected according to viability, dried on paper towels, and incubated in Petri dishes at $27 \pm 1{ }^{\circ} \mathrm{C}$ and relative humidity of $80 \pm 10 \%$. After fifteen days, the egg masses were collected and incubated separately in $5 \mathrm{~mL}$ syringes and in $20 \mathrm{~mL}$ glass tubes. A total of $0.01 \mathrm{~g}$ of eggs were incubated inside each syringe for performing the SIT (SOUZA et al., 2008) and $0.5 \mathrm{~g}$ of eggs were incubated in each assay tube to perform the LPT and LIT.

\section{In vitro assays}

Commercial amitraz (Triatox ${ }^{\circledR}$, MSD, São Paulo, Brazil) was used in the three bioassays (LPT, LIT and SIT) at the following concentrations $(\mu \mathrm{g} / \mathrm{mL}): 10,39,156,625,2500$ and 10000. Each amitraz concentration was tested in triplicate in all the bioassays with each population. The tests were run simultaneously to avoid age interference, and the larvae used were all between 10 and 20 days old. For the LPT and LIT, only larvae presenting negative geotaxis were used. The tubes used for larval hatching were attached to another in the upright position, and only the larvae that were capable of climbing into this other tube were used.

For all three assays, the mortality rate was assessed after the larvae had been exposed to the acaricide for 24 hours. The packets were opened and live and dead larvae were counted. Larvae were considered dead if they were immobile or were only moving their appendages.

\section{Larval packet test (LPT)}

The LPT was performed as described by Miller et al. (2002). Amitraz was dissolved at $1 \%$ in a solution composed of two parts of trichloroethylene and one part of olive oil (TCE-OO). This formulation was subsequently serially diluted in TCE-OO to obtain the six concentrations of amitraz. A sample of $0.67 \mathrm{~mL}$ of each solution was applied to a piece of nylon fabric $(7.5 \times 8.5 \mathrm{~cm})$ (Type 2320, Cerex Advanced Fabrics, Pensacola, FL, USA). The fabrics were left for 24 hours at room temperature to allow evaporation of the trichloroethylene. After the evaporation, nylon fabrics at the same concentrations were grouped, packed in aluminum foil and kept under refrigeration at $4{ }^{\circ} \mathrm{C}$ in individual plastic containers for up to 45 days. On the day of the bioassays, the packets were removed from the refrigerator, folded in half and their sides were sealed with clamps. Using a paintbrush, approximately 100 larvae were placed inside each packet, which was sealed using a third clamp. The packets/syringes containing the larvae were kept at $27 \pm 1{ }^{\circ} \mathrm{C}$ and $80 \pm 10 \%$ relative humidity 
for 24 hours. After this period, the packets were opened and live and dead larvae counted.

\section{Syringe immersion test (SIT)}

The SIT was performed as described by Souza et al. (2008). Eggs were placed in $5 \mathrm{~mL}$ syringes that had previously been prepared by cutting the edge and opening a small orifice of approximately $1 \mathrm{~mm}$ diameter at the $2.5 \mathrm{~mL}$ mark. The plunger was positioned to obstruct the orifice. The open edge was closed with a piece of polyester mesh that was held in place using a piece of orthodontic elastic in order to prevent the larvae from escaping.

Conical glass tubes $(50 \mathrm{~mL})$ were used to dilute the amitraz in distilled water. A volume of $30 \mathrm{~mL}$ of each immersion solution was prepared as described in Section 2. In order to allow the larvae to sink, $10 \mu \mathrm{L}$ of Triton X-100 was added to each dilution. From each solution, $2 \mathrm{~mL}$ was transferred to a microcentrifuge tube which was used in the LIT (see Section 2.3) and the rest was used for the SIT. The immersion time used was longer than recommended by Souza et al. (2008). In preliminary assays, a 5 minute immersion time was determined as having the least error risk. After submerging the syringes inside the conical tubes, the excess solution was removed from the polyester mesh using paper towels. The syringes were then placed for 24 hours, grouped according to concentration, in plastic containers as described for the LPT, and larval mortality was recorded.

\section{Larval immersion test (LIT) modified for microtubes}

The LIT was performed as described by Sabatini et al. (2001), with some modifications. Microtubes (2 mL; Eppendorf ${ }^{\circledR}$ ) containing either the control (distilled water with Triton X-100) or amitraz solutions were used. Using a paintbrush, approximately 400 larvae were submerged in each solution for 5 minutes. The microtubes were then inverted over a Petri dish and the larvae were removed using a paintbrush. One hundred larvae were placed in previously folded filter paper packets $(85 \times 75 \mathrm{~mm})$. Three envelopes for each concentration were placed in plastic containers and were incubated under the same conditions as the LPT, and larval mortality was recorded after 24 hours.

\section{Statistical analyses}

The bioassay data were analyzed by means of probit regression (FINNEY, 1980) using the Polo Plus software (LEORA SOFTWARE, 2004). The following parameters were determined for all the populations of each test: lethal concentration for $50 \%$ $\left(\mathrm{LC}_{50}\right)$ with its $95 \%$ confidence interval $(95 \% \mathrm{CI})$, regression line slope and resistance ratio (RR). The RR was calculated as the quotient between the $\mathrm{LC}_{50}$ of the field population and the $\mathrm{LC}_{50}$ of the susceptible reference strain (SHEPPARD, 1984). Comparisons among the techniques and between field populations were deemed to show significant differences when the calculated 95\% CI of the $\mathrm{LC}_{50}$ did not overlap.

\section{Results}

The results from the LPT, LIT and SIT are respectively presented in Tables 1, 2 and 3. The $\mathrm{LC}_{50}$ of amitraz (95\% CI) (in $\mu \mathrm{g} / \mathrm{mL}$ of active ingredient) of the Mozo strain calculated for the LPT, LIT and SIT were 2.9, 27.3 and 52.7, respectively.

All the populations tested with the LPT were resistant to amitraz (RR between 91.3 and 3422), except for population $2(R R=1.9)$ (Table 1). In general, a good fit to the probit model was achieved with the LPT, and it was possible to calculate the $\mathrm{LC}_{50}$ for all the populations tested. In most of the cases, the 95\% CI was narrow.

In six populations tested with the LIT (sample numbers 3, 4, 6, 7, 11 and 13), the $\mathrm{LC}_{50}$ could not be calculated because of low slope values. Also, 95\% CI of high amplitude for the calculated $\mathrm{LC}_{50}$ was observed from the immersion technique in some cases (samples 2, 21A, 22B and 22C). A good fit to the probit model was obtained with eight populations (samples 1, 8, 9, 10, 12, 15, 20 and 24). All these populations were considered to be resistant to amitraz (Table 2).

In Table 3, the data obtained from the SIT are presented. In general, a poor fit to the probit model was observed. It was impossible to calculate the $\mathrm{LC}_{50}$ for most of the populations tested, because of low slope values and/or high heterogeneity of the results. According to the $\mathrm{LC}_{50}$ calculated from this bioassay, all the populations were considered to be resistant to amitraz, except for population 1 .

\section{Discussion}

The LPT was modified for amitraz by Miller et al. (2002), and this test has been recognized and accepted by the UN Food and Agriculture Organization (FAO, 2004) for diagnosing resistance to amitraz. For this reason, it was used as the reference test in this study. The SIT was described by Souza et al. (2008) and has not yet been standardized. The LIT was described by Shaw (1966) and several adaptations and modifications have been made over the years. Although this assay has not yet been recognized by FAO as a trustworthy method for detecting acaricide resistance in tick populations, it has been used to assess the toxicity of chemicals that act systemically, such as fipronil (CASTRO-JANER et al., 2010) and ivermectin (KLAFKE et al., 2006, 2012). Recently, it was described as a reliable method for detecting resistance to amitraz (MENDES et al., 2013).

The detection of 19 amitraz-resistant populations using the LPT (Table 1) supports the results obtained by Santos et al. (2008), who detected low in vitro efficacy levels in relation to amitraz, in the southern region of Rio Grande do Sul using the adult immersion test. According to the results obtained in the present study, 95\% of the assessed populations assessed were resistant to amitraz $(R R \geq 91.3)$. Therefore, it seems that resistance to this acaricide is widespread in the region studied.

Comparative analysis between the LPT and the LIT was only possible in 14 populations and the $\mathrm{LC}_{50}$ and $\mathrm{RR}$ were not coherent among them (Tables 1 and 2). For example, while population 2 was considered to be susceptible to amitraz according to the LPT, 
Table 1. Results from the modified larval packet test (LPT) for amitraz in Rhipicephalus (B.) microplus from the Mozo susceptible strain and from field samples from the state of Rio Grande do Sul, Brazil.

\begin{tabular}{|c|c|c|c|c|c|}
\hline Population & $\mathbf{n}$ & $\chi^{2}(\mathrm{df})$ & Slope (SE) & $\begin{array}{c}\mathrm{LC}_{50}(\mu \mathrm{g} / \mathrm{mL}) \\
(95 \% \mathrm{CI})\end{array}$ & $\mathbf{R R}$ \\
\hline Mozo & 1092 & $11.4(10)$ & $1.184(0.16)$ & $\begin{array}{c}2.9 \\
(1.0-5.3)\end{array}$ & - \\
\hline 1 & 2937 & $250(16)$ & $4.363(0.25)$ & $\begin{array}{c}1155.4 \\
(718.0-1626.0)\end{array}$ & 398.4 \\
\hline 2 & 2330 & $137.8(16)$ & $0.686(0.04)$ & $\begin{array}{c}5.5 \\
(0.9-13.7)\end{array}$ & 1.9 \\
\hline 3 & 2013 & $156.8(16)$ & $1.629(0.14)$ & $\begin{array}{c}7549.7 \\
(4656.8-20590.7)\end{array}$ & 2621.4 \\
\hline 4 & 1413 & $84.3(10)$ & $3.284(0.22)$ & $\begin{array}{c}1989.2 \\
(1364.1-2762.2)\end{array}$ & 685.9 \\
\hline 6 & 2099 & $59.2(10)$ & $2.968(0.14)$ & $\begin{array}{c}1842.5 \\
(1461.8-2290.1)\end{array}$ & 635.3 \\
\hline 7 & 2340 & $385.3(16)$ & $1.079(0.05)$ & $\begin{array}{c}305.5 \\
(81.0-762.7)\end{array}$ & 105.3 \\
\hline 8 & 2628 & $105.1(16)$ & $0.394(0.03)$ & $\begin{array}{c}264.9 \\
(79.4-706.1)\end{array}$ & 91.3 \\
\hline 9 & 5123 & $794.2(10)$ & $0.651(0.02)$ & $\begin{array}{c}431.7 \\
(61.0-5177.9)\end{array}$ & 148.9 \\
\hline 10 & 4201 & $1364.9(10)$ & $1.122(0.03)$ & $\begin{array}{c}431.7 \\
(145.2-1423.7)\end{array}$ & 148.9 \\
\hline 11 & 2389 & $167.8(16)$ & $1.56(0.06)$ & $\begin{array}{c}770.7 \\
(521.1-1112.1)\end{array}$ & 265.8 \\
\hline 12 & 3046 & $297.2(16)$ & $1.469(0.04)$ & $\begin{array}{c}685.7 \\
(410.5-1121.3)\end{array}$ & 236.4 \\
\hline 13 & 3765 & $685.6(16)$ & $0.947(0.04)$ & $\begin{array}{c}9923.9 \\
(3844.2-88088.1)\end{array}$ & 3422 \\
\hline 14 & 2859 & $143.44(10)$ & $2.014(0.08)$ & $\begin{array}{c}1322.8 \\
(556.7-2600.7)\end{array}$ & 456.1 \\
\hline 15 & 1081 & $87.9(10)$ & $1.174(0.06)$ & $\begin{array}{c}446.1 \\
(232.3-884.3)\end{array}$ & 153.8 \\
\hline 19 & 2492 & $84.6(10)$ & $1.772(0.11)$ & $\begin{array}{c}4334.5 \\
(2882.4-6711.8)\end{array}$ & 1494.6 \\
\hline 20 & 2397 & $25.2(10)$ & $2.889(0.14)$ & $\begin{array}{c}2055.8 \\
(1772.6-2370.1)\end{array}$ & 708.9 \\
\hline $21 \mathrm{~A}$ & 1607 & $42.3(10)$ & $0.952(0.04)$ & $\begin{array}{c}552.3 \\
(367.7-858)\end{array}$ & 190.4 \\
\hline $22 B$ & 1473 & $11.6(10)$ & $0628(0.04)$ & $\begin{array}{c}3087.7 \\
(2082.7-4981.9)\end{array}$ & 1064.7 \\
\hline $23 \mathrm{C}$ & 1740 & $44.6(10)$ & $0.964(0.04)$ & $\begin{array}{c}455.8 \\
(306.8-685.7)\end{array}$ & 157.2 \\
\hline 24 & 3318 & $478.8(10)$ & $1.238(0.04)$ & $\begin{array}{c}476.9 \\
(177.1-1125.2)\end{array}$ & 164.4 \\
\hline
\end{tabular}

$\mathrm{N}$ : number of larvae; $\chi^{2}$ : chi-square; df: degrees of freedom; SE: standard error; $\mathrm{LC}_{50}$ : median lethal concentration; $95 \% \mathrm{CI}$ : $95 \%$ confidence interval; $\mathrm{RR}$ : resistance ratio.

because of a RR of 1.9, this population was categorized as being resistant according to the LIT, because of a RR of 178.2.

Regarding the SIT (Table 3), $\mathrm{LC}_{50}$ could only be calculated in seven populations. Determination of the $\mathrm{LC}_{50}$ using the SIT was only possible in six populations assessed by this technique. The RRs values obtained through this bioassay were lower than those obtained using the LPT and LIT for the same field isolates. This was probably due to the high $\mathrm{LC}_{50}$ obtained for the susceptible Mozo strain.

The high divergence in the parameters determined using each of the assays may be associated with factors intrinsic of the tests. In the SIT, despite preliminary selection of the syringes used, some larvae may not have been fully active, which would once again result in higher mortality rates than expected. 
Table 2. Results from the larval immersion test (LIT) for amitraz in Rhipicephalus (Boophilus) microplus from the Mozo strain and from field samples from the state of Rio Grande do Sul, Brazil.

\begin{tabular}{|c|c|c|c|c|c|}
\hline Population & $\mathbf{N}$ & $\chi^{2}(\mathrm{df})$ & Slope (SE) & $\begin{array}{c}\mathrm{LC}_{50}(\mu \mathrm{g} / \mathrm{mL}) \\
(95 \% \mathrm{CI})\end{array}$ & $\mathbf{R R}$ \\
\hline Mozo & 1637 & $43.5(10)$ & $0.997(0.06)$ & $\begin{array}{c}27.3 \\
(14.7-43.3)\end{array}$ & - \\
\hline 1 & 3667 & $157.1(16)$ & $2.66(0.12)$ & $\begin{array}{c}604.1 \\
(442.5-778.1)\end{array}$ & 22.1 \\
\hline 2 & 2432 & $475(16)$ & $0.977(0.05)$ & $\begin{array}{c}4865.6 \\
(1685.3-42124.8)\end{array}$ & 178.2 \\
\hline 3 & 1735 & $69.9(16)$ & $0.13(0.04)$ & - & - \\
\hline 4 & 557 & $21.9(10)$ & $0.552(0.26)$ & - & - \\
\hline 6 & 1461 & $11.6(10)$ & $0.212(0.07)$ & - & - \\
\hline 7 & 1673 & $143.5(16)$ & $0.243(0.03)$ & - & - \\
\hline 8 & 3546 & $117.5(16)$ & $1.207(0.03)$ & $\begin{array}{c}437.9 \\
(328.3-585.8)\end{array}$ & 16 \\
\hline 9 & 1734 & $98.5(10)$ & $1.925(0.15)$ & $\begin{array}{c}348.1 \\
(102.5-585.1)\end{array}$ & 12.8 \\
\hline 10 & 1783 & $59.7(10)$ & $1.47(0.06)$ & $\begin{array}{c}446.2 \\
(329.5-581.4)\end{array}$ & 16.3 \\
\hline 11 & 1005 & $8411.7(16)$ & $0.129(0.04)$ & - & - \\
\hline 12 & 1724 & $148(16)$ & $0.951(0.04)$ & $\begin{array}{c}349.8 \\
(201.2-638.6)\end{array}$ & 12.8 \\
\hline 13 & 1519 & $30.5(16)$ & $-0.109(0.08)$ & - & - \\
\hline 14 & 3030 & $181.1(10)$ & $2.127(0.12)$ & $\begin{array}{c}531.1 \\
(244.4-847.9)\end{array}$ & 19.5 \\
\hline 15 & 1920 & $63.9(10)$ & $6.846(0.46)$ & $\begin{array}{c}1024.9 \\
(807.9-1355.7)\end{array}$ & 37.5 \\
\hline 19 & 2123 & $150(9)$ & $3.1(0.23)$ & $\begin{array}{c}2332.3 \\
(1164.1-4272.2)\end{array}$ & 85.43 \\
\hline 20 & 1787 & $50.5(10)$ & $2.571(0.21)$ & $\begin{array}{c}3026.8 \\
(2242.8-3911.2)\end{array}$ & 110.8 \\
\hline $21 \mathrm{~A}$ & 1464 & $27.8(10)$ & $0.387(0.04)$ & $\begin{array}{c}17456.2 \\
(5428.9-150932.9)\end{array}$ & 639.4 \\
\hline $22 \mathrm{~B}$ & 1549 & $8.6(10)$ & $0.431(0.04)$ & $\begin{array}{c}7359.1 \\
(4370.6-14393.4)\end{array}$ & 269.6 \\
\hline $23 \mathrm{C}$ & 1317 & $67.8(10)$ & $0.411(0.04)$ & $\begin{array}{c}62345.8 \\
(7956.4-51772826.4)\end{array}$ & 2283.7 \\
\hline 24 & 1829 & $19.3(9)$ & $4.54(0.41)$ & $\begin{array}{c}3263.1 \\
(2907.3-3741.6) \\
\end{array}$ & 119.52 \\
\hline
\end{tabular}

$\mathrm{N}$ : number of larvae; $\chi^{2}$ : chi-square; df: degrees of freedom; SE: standard error; $\mathrm{LC}_{50}$ : median lethal concentration; $95 \%$ CI: $95 \%$ confidence interval;

$\mathrm{RR}$ : resistance ratio.

Furthermore, in carrying out the SIT, moving the plunger to remove the amitraz solution after the immersion may kill some of the larvae by crushing them. This risk is absent in the other assays. The fabric used to seal the syringes may also hold amitraz residues, even after drying. This would allow greater exposure of the larvae to the acaricide, taking into account the 24-hour incubation period prior to assessment.

When Souza et al. (2008) described the SIT, they also observed higher mortality rates than what was expected in the solutions with lower amitraz concentrations. This interfered with their calculation of the $\mathrm{LC}_{50}$, and they explained these variations as experimental error. However, the results obtained in the present study suggest that those observations were not mistakes, but limitations of the technique, since calculation of the RR was possible for only seven out of the 20 populations.

Use of in vitro assays to monitor the efficacy of amitraz in the field requires specific training for laboratory personnel. Since amitraz is still widely used in the southern region of Rio Grande do Sul, there is a strong need to develop an assay that would be easier and faster to perform than the LPT. The results obtained in the present study limit the recommendation for using the SIT and LIT to diagnose amitraz-resistant tick populations. 
Table 3. Results from the syringe immersion test (SIT) for amitraz in Rhipicephalus (B.) microplus from the Mozo strain and from field samples from the state of Rio Grande do Sul, Brazil.

\begin{tabular}{|c|c|c|c|c|c|}
\hline Population & $\mathbf{n}$ & $\chi^{2}$ (df) & Slope & $\begin{array}{c}\mathrm{LC}_{50}(\mu \mathrm{g} / \mathrm{mL}) \\
(95 \% \mathrm{CI})\end{array}$ & $\mathbf{R R}$ \\
\hline Mozo & 1169 & $39.3(10)$ & $1.239(0.07)$ & $\begin{array}{c}52.7 \\
(34.5-78.0)\end{array}$ & - \\
\hline 1 & 3243 & $539.2(16)$ & $0.712(0.03)$ & $\begin{array}{c}49.8 \\
(9.4-138.9)\end{array}$ & 0.9 \\
\hline 2 & 4315 & $802.2(16)$ & $0.483(0.03)$ & - & - \\
\hline 3 & 3191 & $646.7(16)$ & $-0.355(0.02)$ & - & - \\
\hline 4 & 945 & $210.8(10)$ & $3.069(0.42)$ & - & - \\
\hline 6 & 2525 & $133.6(10)$ & $14.345\left(0.38 \times 10^{6}\right)$ & - & - \\
\hline 7 & 2888 & $532.8(16)$ & $0.549(0.03)$ & $\begin{array}{c}674.8 \\
(184.6-6202.6)\end{array}$ & 12.8 \\
\hline 8 & 4333 & $461.2(16)$ & $6.255(0.42)$ & - & - \\
\hline 9 & 3648 & $671.3(10)$ & $0.464(0.02)$ & - & - \\
\hline 10 & 3258 & $437.5(10)$ & $16.104\left(0.63 \times 10^{6}\right)$ & - & - \\
\hline 11 & 1005 & $190.9(12)$ & $0.129(0.04)$ & - & - \\
\hline 12 & 1253 & $344.7(16)$ & $0.416(0.05)$ & - & - \\
\hline 13 & 3521 & $1005.7(16)$ & $0.016(0.026)$ & - & - \\
\hline 14 & 2248 & $462(10)$ & $0.655(0.04)$ & - & - \\
\hline 15 & 3142 & $250.7(10)$ & $2.105(0.16)$ & - & - \\
\hline 19 & 1625 & $267.3(9)$ & $1.187(0.116)$ & - & - \\
\hline 20 & 1926 & $69.8(10)$ & $4.824(0.31)$ & $\begin{array}{c}3692.6 \\
(2939.4-4754.3)\end{array}$ & 70.1 \\
\hline $21 \mathrm{~A}$ & 1299 & $37.6(10)$ & $0.398(0.04)$ & $\begin{array}{c}1422.4 \\
(568.7-5494.2)\end{array}$ & 26.9 \\
\hline $22 \mathrm{~B}$ & 1327 & $28.5(10)$ & $0.437(0.04)$ & $\begin{array}{c}1512.8 \\
(725.1-4087.7)\end{array}$ & 28.7 \\
\hline $23 \mathrm{C}$ & 1511 & $19.2(10)$ & $0.489(0.04)$ & $\begin{array}{c}2296.9 \\
(1103.7-5335.2)\end{array}$ & 43.6 \\
\hline 24 & 1442 & $50.7(10)$ & $2.4(0.15)$ & $\begin{array}{c}1678.9 \\
(1168.0-2253.8)\end{array}$ & 31.9 \\
\hline
\end{tabular}

$\mathrm{N}$ : number of larvae; $\chi^{2}$ : chi-square; df: degrees of freedom; SE: standard error; $\mathrm{LC}_{50}$ : median lethal concentration; $95 \%$ CI: $95 \%$ confidence interval; RR: resistance ratio.

\section{Acknowledgements}

To the Research Support Foundation of Rio Grande do Sul (Fundação de Amparo a Pesquisa do Rio Grande do Sul, FAPERGS) for funding this project (0904818 - ARD 03/2009).

To Dr. João Ricardo Martins of the "Desidério Finamor" Veterinary Research Institute (Instituto de Pesquisas Veterinárias Desidério Finamor), Eldorado do Sul, RS, for donating the Mozo strain and the nylon fabric for use in the LPT modified for amitraz.

\section{References}

Andreotti R, Guerreiro FD, Soares MA, Barros JC, Miller RJ, León AP. Acaricide resistance of Rhipicephalus (Boophilus) microplus in State of Mato Grosso do Sul, Brazil. Rev Bras Parasitol Vet 2011; 20(2): 127 133. PMid:21722487. http://dx.doi.org/10.1590/S198429612011000200007

Camillo G, Vogel FF, Sangioni LA, Cadore GC, Ferrari R. Eficiência in vitro de acaricidas sobre carrapatos de bovinos no Estado do Rio
Grande do Sul, Brasil. Cienc Rural 2009; 39(2): 490-495. http://dx.doi. org/10.1590/S0103-84782008005000082

Campos Júnior DA, Oliveira PR. Avaliação in vitro da eficácia de acaricidas sobre Boophilus microplus (Canestrini, 1887) (Acari: Ixodidae) de bovinos no município de Ilhéus, Bahia, Brasil. Cienc Rural 2005; 35(6):13861392. http://dx.doi.org/10.1590/S0103-84782005000600025

Castro-Janer E, Martins JR, Mendes MC, Namindome A, Klafke GM, Schumaker TTS. Diagnoses of fipronil resistance in Brazilian cattle ticks (Rhipicephalus (Boophilus) microplus) using in vitro larval bioassays. Vet Parasitol 2010; 173(3-4): 300-306. PMid:20688434. http://dx.doi. org/10.1016/j.vetpar.2010.06.036

Crow JF. Genetics of insect resistance to chemicals. Ann Rev Entomol 1957; 2(2): 227-246. http://dx.doi.org/10.1146/annurev. en.02.010157.001303

Food and Agriculture Organization - FAO. Recommended methods for the detection and measurement of resistance of agricultural pests to pesticides - tentative method for larvae ticks, Boophilus spp. Rome: Food and Agriculture Organization; 1971. Bull. v. 19, p. 15-18. 
Food and Agriculture Organization - FAO. Resistance Management and Integrated Parasite Control in Ruminants - Guidelines, Module 1 - Ticks: Acaricide Resistance: Diagnosis, Management and Prevention. Rome: Food and Agriculture Organization, Animal Production and Health Division; 2004

Farias NAR, Ruas JL, Santos TRB. Análise da eficácia de acaricidas sobre o carrapato Boophilus microplus, durante a última década, na região sul do Rio Grande do Sul. Cienc Rural 2008; 38(6): 1700-1704. http://dx.doi. org/10.1590/S0103-84782008000600032

Finney DJ. Probit Analysis. 3rd ed. Cambridge: Cambridge University Press; 1980

Klafke GM, Sabatini GA, Albuquerque TA, Martins JR, Kemp DH, Miller RJ, et al. Larval immersion tests with ivermectin in populations of the cattle tick Rhipicephalus (Boophilus) microplus (Acari: Ixodidae) from State of Sao Paulo, Brazil. Vet Parasitol 2006; 142(3-4): 386-390. PMid:16904265. http://dx.doi.org/10.1016/j.vetpar.2006.07.001

Klafke GM, Castro-Janer E, Mendes MC, Namindome A, Schumaker TTS. Applicability of in vitro bioassays for the diagnosis of ivermectin resistance in Rhipicephalus microplus (Acari: Ixodidae). Vet Parasitol 2012; 184(2-4): 212-220. PMid:21978742. http://dx.doi. org/10.1016/j.vetpar.2011.09.018

Kunz SE, Kemp DH. Insecticides and Acaricides: resistance and environmental impact. Rev Sci Tech Off Int Epiz 1994; 13(4): 1249-1286.

Leora Software. Polo Plus Probit and Analysis: User's Guide Berkeley. USA; 2004.36 p.

Li AY, Davey RB, Miller RJ, George JE. Mode of inheritance of amitraz resistance in a Brazilian strain of the southern cattle tick, Boophilus microplus (Acari: Ixodidae). Exp Appl Acarol 2005; 37(3-4): 183-198. PMid:16323050. http://dx.doi.org/10.1007/s10493-005-3260-9

Mendes EC, Mendes MC, Sato ME. Diagnosis of amitraz resistance in Brazilian populations of Rhipicephalus (Boophilus) microplus (Acari: Ixodidae) with larval immersion test. Exp Appl Acarol 2013; 61 (3): 357369. http://dx.doi.org/10.1007/s10493-013-9697-3

Miller RJ, Davey RB, George JE. Modification of the Food and Agriculture Organization Larval Packet Test to Measure Amitraz-
Susceptibility Against Ixodidae. J Med Entomol 2002; 39(4): 645-651. PMid:12144297. http://dx.doi.org/10.1603/0022-2585-39.4.645

Sabatini GA, Kemp DH, Hughes S, Nari A, Hansen J. Tests to determine LC50 and discriminating doses for macrocyclic lactones against the cattle tick, Boophilus microplus. Vet Parasitol 2001; 95(1): 53-62. http://dx.doi. org/10.1016/S0304-4017(00)00406-4

Santos TRB, Farias NAR, Cunha NA Fo, Vaz IS Jr. Uso de acaricidas em Rhipicephalus (B.) microplus de duas regiōes fisiográficas do Rio Grande do Sul. Acta Sci Vet 2008; 36(1): 25-30.

Santos TRB, Pappen FG, Farias NAR, Vaz IS Jr. Análise in vitro da eficácia do amitraz sobre populaçóes de Rhipicephalus (Boophilus) microplus (Canestrini, 1887) da regiáo sul do Rio Grande do Sul. Rev Bras Parasitol Vet 2009; 18(S1): 54-57. PMid:20040192. http://dx.doi. org/10.4322/rbpv.018e1010

Shaw RD. Culture of an organophosphorus-resistant strain of Boophilus microplus (Can.) and an assessment of its resistance spectrum. Bull Entomol Res 1966; 56(3): 389-405. PMid:5945563. http://dx.doi. org/10.1017/S0007485300056480

Sheppard DC. Fenvalerate and Flucythrinate resistance in a horn fly population. J Agric Entomol 1984; 1(3): 305-310.

Souza AP, Veiga LPHN, Bellato V, Sartor AA, Cardoso CP, Nunes APO. Proposta para teste carrapaticida por imersão de larvas de Rhipicephalus (Boophilus) microplus: avaliação em cipermetrina e amitraz. Rev Bras Parasitol Vet 2008; 17(4): 242-245. PMid:19265586.

Stone BF, Haydock KP. A method for measuring the acaricidesusceptibility of the cattle tick Boophilus microplus (Can.). Bull Entomol Res 1962; 53(3): 563-578. http://dx.doi.org/10.1017/ S000748530004832X

Vargas MS, Céspedes NS, Sánchez HF, Martins JR, Céspedes COC. Avaliação in vitro de uma cepa de campo de Boophilus microplus (Acari: Ixodidae) resistente à Amitraz. Cienc Rural 2003; 33(4): 737-742.

Veiga LPHN, Souza AP, Bellato V, Sartor AA, Nunes APO, Cardoso HM. Resistance to cypermethrin and amitraz in Rhipicephalus (Boophilus) microplus on the Santa Catarina Plateau, Brazil. Rev Bras Parasitol Vet 2012; 21(2): 133-136. http://dx.doi.org/10.1590/S198429612012000200011 